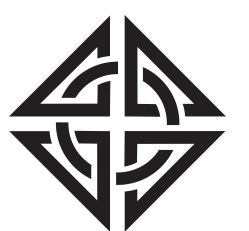

SCIENTIA
Sharif University of Technology

Scientia Iranica

Transactions A: Civil Engineering

http://scientiairanica.sharif.edu

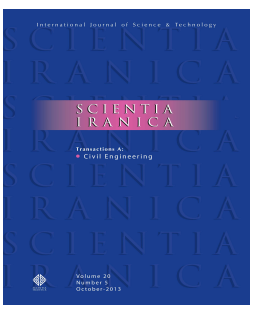

\title{
Mitigating the uneven settlement of nearby strip footings on loose saturated sand using concrete pedestals: A model test study
}

\author{
S. Salamatpoor ${ }^{\mathrm{a}}$, Y. Jafarian ${ }^{\mathrm{b}, *}$, and A. Hajiannia ${ }^{\mathrm{a}}$ \\ a. Department of Civil Engineering, Najafabad Branch, Islamic Azad University, Najafabad, Isfahan, Iran. \\ b. Geotechnical Engineering Research Center, International Institute of Earthquake Engineering and Seismology, Tehran, Iran.
}

Received 13 February 2018; received in revised form 30 April 2018; accepted 26 May 2018

\author{
KEYWORDS \\ Strip footing; \\ Sand; \\ Pedestal; \\ Settlement; \\ Tilt; \\ Bearing capacity; \\ Model test.
}

\begin{abstract}
Adjacency and interference of the footings are of importance in geotechnical engineering. Researchers have studied the behavior of adjacent footings by several approaches; however, the load-deformation mechanism used for such footings under unequal and non-simultaneous surcharges has not been explored to date. In this study, two series of experiments were conducted using small-scale $1 \mathrm{~g}$ models to investigate the behavior of two adjacent footings under reinforced and unreinforced soil conditions. The footings were installed with different side-to-side spacing and placed on loose saturate sand. The ultimate bearing capacity, settlement, and tilting of footings were evaluated when: (1) the footings rested on unreinforced sand and (2) the soil underneath the new footing was reinforced by concrete pedestals. The results indicated that reinforcing the new footing by three concrete pedestals at a spacing to footing's width ratio $(S / B)$ of 0 (i.e., two coherent footings) led to increasing the bearing capacity of the new footing by $67 \%$, compared to that of the unreinforced condition. Moreover, the settlement and tilting of the old footing adjacent to the new footing decreased up to $250 \%$ and $600 \%$, respectively, in comparison to those of the unreinforced condition.

(C) 2020 Sharif University of Technology. All rights reserved.
\end{abstract}

\section{Introduction}

The design and construction of foundations in soft soils are one of the most significant and challenging processes for engineers since any possible weakness in foundations may result in potential damage to structures. In the current practice, due to the population growth and land scarcity, structures are constructed in close proximity. In areas where heavy buildings

*. Corresponding author.

E-mail addresses: ssalamatpoor@sci.iaun.ac.ir (S.

Salamatpoor); yjafarianm@iiees.ac.ir (Y. Jafarian);

alborzhajian@pci.iaun.ac.ir (A.Hajiannia)

doi: $10.24200 /$ sci.2018.50450.1698 are constructed next to light buildings, the stability of the adjacent light buildings is threatened by the probable uneven settlement due to the neighbor surcharge. Therefore, investigating the adjacency effect and mitigation techniques on the bearing capacity, settlement, and tilting seems to be essential in the soft grounds.

Many previous studies have focused on the ultimate bearing capacity of the interfering footings resting on unreinforced and reinforced soil conditions (e.g., [1-8]). Stuart [1] utilized the limit equilibrium method to evaluate the interference effect of two strip footings on their ultimate bearing capacity, and found that changes in spacing between the footings caused variation in their ultimate bearing capacity. Research on the interference effects of two closely spaced footings 
on reinforced sand indicates that sand reinforcement definitely improves the mechanical performance of the nearby footings. Ghazavi and Alimardani Lavasan [2] studied the interference effect of shallow foundations constructed on sand reinforced with geosynthetics. They explored the role of the contributing parameters in the interference factor including the reinforcement location and the distance between the two close footings. Srinivasan and Ghosh [5] experimentally investigated the interaction between two nearby circular surface footings by conducting a number of laboratory scaled model tests on a dry and cohesionless Ennore sand stratum. The experimental study indicated that the ultimate bearing capacity of the two interfering footings increased by decreasing the spacing between the footings. A review of the previous works indicates that the load-deformation mechanism of nearby foundations with unequal and non-simultaneous surcharging has been rarely addressed, while this type of proximity is more prevalent in urban areas.

In a recent paper [9], the authors presented the results of various tests on nearby strip footing with the loading specifications mentioned above, and found that detrimental uneven settlement occurred due to proximate loading. The current paper aims to reveal the results of the mitigation technique applied to minimize the potential damage of the light footing, which generally settles in an asymmetric fashion. In the first part of this study, the interfering effect of two adjacent footings on their ultimate bearing capacity, settlement, and tilting is studied briefly by conducting ten smallscale $1 \mathrm{~g}$ model tests. It is indicated that one of the two considered footings represents the light building (the old footing), and the second one is the sample of the new heavy building. In other words, the nearby footings have unequal and separate loading conditions. In the second step, six small-scale $1 \mathrm{~g}$ model tests are performed as the main part of this investigation to assess the influence of the improvement of the soil underneath the new footing on the interference effects between the footings.

\section{Experimental works}

\subsection{Material properties}

\subsubsection{Sand}

The soil used in this study is the Babolsar sand and was sampled from the southern shores of the Caspian Sea in Mazandaran province, Iran. The sand is poorly graded and is classified as SP according to the unified soil classification system (ASTM D422 [10]). Figure 1 and Table 1 represent the grains size distribution curve and basic properties of the sand, respectively.

The groundwater is close to the ground surface and, also, the region has high seismic potential due to the Khazar fault. In the past, several catastrophic

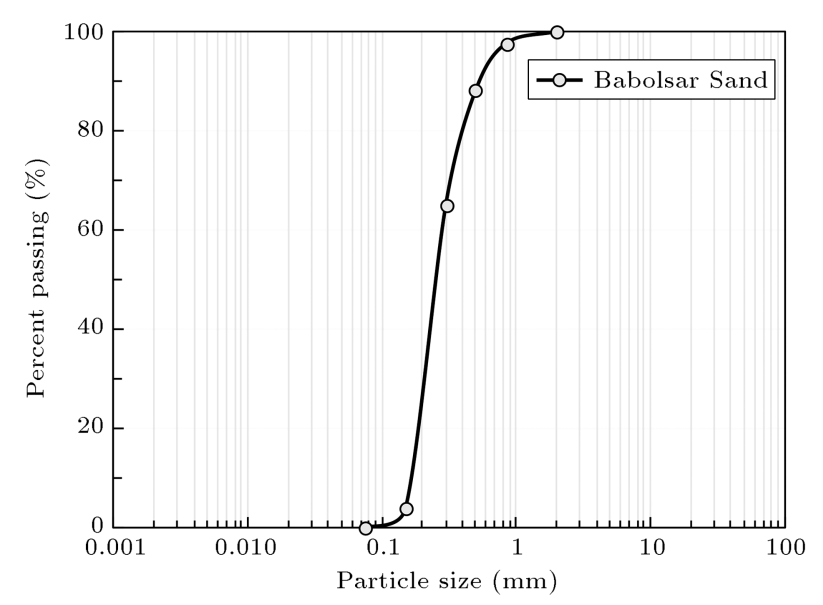

Figure 1. Particle size distribution curves of Babolsar sand.

Table 1. Basic properties of Babolsar sand.

\begin{tabular}{lccccc}
\hline & $\begin{array}{c}\left(\gamma_{d}\right)_{\max } \\
\left(\mathbf{k N} / \mathbf{m}^{\mathbf{3}}\right)\end{array}$ & $\begin{array}{c}\left(\gamma_{\boldsymbol{d}}\right)_{\min } \\
\left(\mathbf{k N} / \mathbf{m}^{\mathbf{3}}\right)\end{array}$ & $\boldsymbol{G}_{\boldsymbol{s}}$ & $\begin{array}{c}\boldsymbol{D}_{\mathbf{5 0}} \\
(\mathbf{m m})\end{array}$ & $\boldsymbol{C}_{\boldsymbol{u}}$ \\
\hline Babolsar sand & 17 & 15.1 & 2.78 & 0.24 & 1.8 \\
\hline
\end{tabular}

earthquakes took place near Babolsar city such as the Bandpey 1957 earthquake $\left(M_{w}=7\right)$, which caused more than 1500 deaths and 120 villages destruction. Therefore, the occurrence of liquefaction is likely, and investigating the behavior of shallow foundations on the loose saturated Babolsar sand in the area seems to be essential. Jafarian et al. [11] evaluated the monotonic behavior of the Babolsar sand through the triaxial tests under isotropic and anisotropic consolidations. Moreover, Jafarian et al. [12] evaluated the shear strain-dependent dynamic properties of this sand using resonant column and cyclic triaxial experiments. Further, Salamatpoor and Salamatpoor [13] compared the liquefaction potential of the Babolsar sand with thirteen case histories using the concept of the liquefied shear strength ratio. The results of these studies indicated that the Babolsar sand was potentially susceptible to significant strain softening due to monotonic and cyclic loads. Since the region is densely populated and numerous shallow foundations have been constructed, sand improvement studies are necessary to reduce the probable risks that arise from the shear failure of foundations in these areas.

\subsubsection{Cement}

In this paper, Portland cement type II (ASTM C150/C150M-17 [14]) was utilized in the experiments. This type of cement, which is appropriate for the structures exposed to soil or water containing sulfate ions, was obtained from Mazandaran Cement Company as the most widely used cement in the construction industry in North of Iran. 


\subsection{Test facilities, instrumentation, and model preparation}

The equipment used in this part of the study consists of a frame, transparent tanks, and measuring instruments. The frame, which carries the applied load by a jack, is composed of IPE 16 screwed to the rigid foundation with eight M22 bolts. In addition, the angle bars and reinforcements were welded to the frame to avoid any possible displacement. The transparent tank, designed as a rigid box, was made up of 4 sheets of a $20-\mathrm{mm}$ thick acrylic plate with a length of $94 \mathrm{~cm}$, width of $40 \mathrm{~cm}$, and height of $94 \mathrm{~cm}$. In fact, for a visual observation of soil deformation underneath the foundation or tracking the wedge failure behavior, the tank was made up of transparent sheets.

To strengthen the test tank, a metal frame was used in conjunction with all the transparent walls. The strip footing with $15 \times 40 \mathrm{~cm}$ dimensions was made with a thick steel sheet, and some stiffeners were welded to the upper part of the sheets to ensure rigidity. Since the inside width of the box was equal to the length of the model foundations, a plain-strain condition was generally maintained [15]. Before conducting the tests, for each test, some preliminary works such as calibrating the load cell, dialing gauge, and depleting the piezometer tubes from the air were required to ensure higher precision. To achieve the required uniformity in the model, the sedimentation of soils in nature was mimicked for the sand deposition. First, the tank was filled with de-aired water up to the height of $70 \mathrm{~cm}$. Then, the sands, dried in an oven for 24 hours, were gradually poured into the water from a constant height of $2 \mathrm{~cm}$ above the water surface by a sand rainer to achieve the desired loose density. Since the width and the length of the testing tank were constant, the relative density was controlled by measuring the height (or volume) and the weight of each layer. An attempt was made to reconstitute the model sand deposit at a relative density $\left(D_{r}\right)$ of $30 \pm 2 \%$ through a water sedimentation process [15].

The depth of sand deposit was $70 \mathrm{~cm}$ for the tests, providing enough thickness for the failure surface caused by the load applied to the foundation plate. This issue was checked through the finite element modeling of the model test and the procedure of loading application. For the foundation width (i.e., $15 \mathrm{~cm}$ ) and the maximum surcharge $(100 \mathrm{kPa})$ specified in the experiments, the required sand depth and the total width of the model box were found to be $70 \mathrm{~cm}$ and $70 \mathrm{~cm}$, respectively, based on the finite element modeling. For the sake of brevity, the details of the finite element modeling are not given in this paper.

The vertical load was applied by a 1.5-ton jack, whereas the corresponding footing settlement was measured by a load cell and three dial gauges. The time of model preparation and testing procedure was about

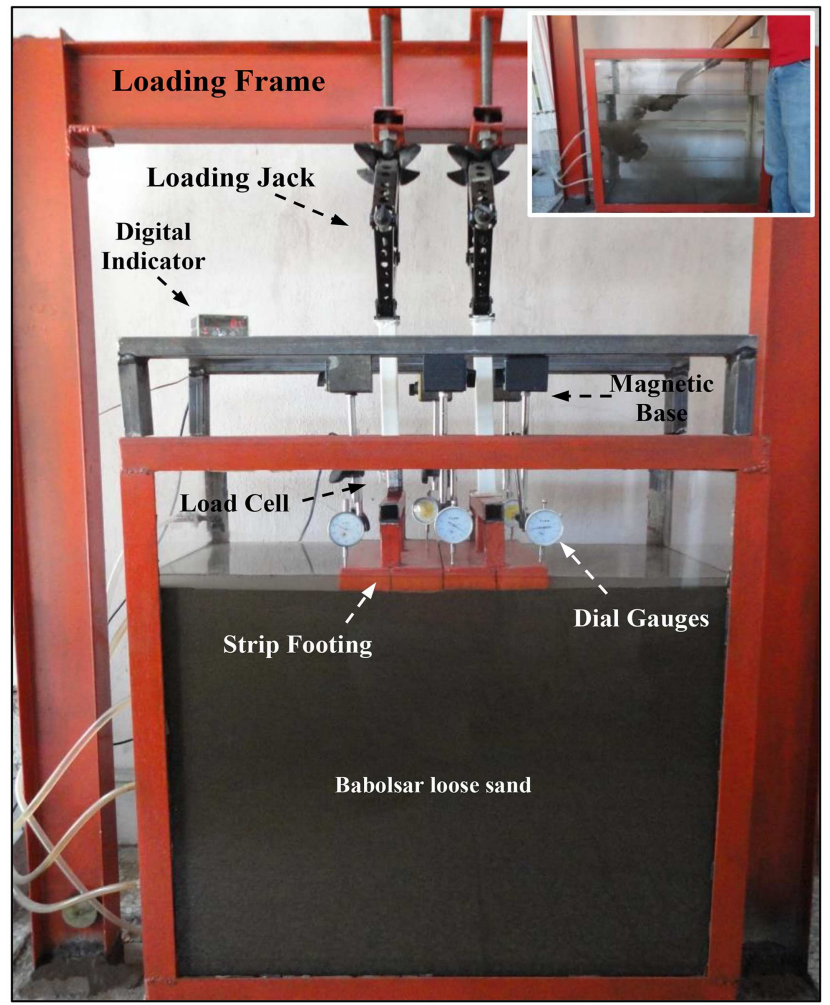

Figure 2. Details of small-scale $1 \mathrm{~g}$ model tests apparatus.

8 hours and all the described steps were repeated for each test. The device and utilities were specifically designed and constructed for this study. Figures 2 and 3 illustrate the equipment and model preparation steps used in the experiments and the schematic view of the experimental setup, respectively.

\subsection{Model scaling}

Physical modeling is divided into two categories: smallscale model and full-scale model. Full-scale physical modeling can simulate the real site conditions such as ground conditions, pressures, and stress levels. However, due to difficulties in preparing the conditions for this type of modeling and its high cost, the researchers encourage the use of small-scale physical models using the theory of similarity and scaling law.

Based on ASTM D1194-72 [16] for plate load tests in granular soils, the replacement of a prototype with a plate $N$ times smaller in dimensions results in an ultimate bearing capacity $N$ times smaller than that of the prototype. In this study, a small-scale model with a ratio 10 times smaller than the hypothesized prototype was built. Since the stress levels are low in small-scale modeling, the stress-strain behavior of the prototype is considered for the model, too. Moreover, the scaling factors are assumed in this study. Table 2 shows the applied theory of scaling law defined by Wood [17]. Jafarian et al. [18] applied the Vargas-Monge [19] data and the brittleness index concept proposed by Bishop 


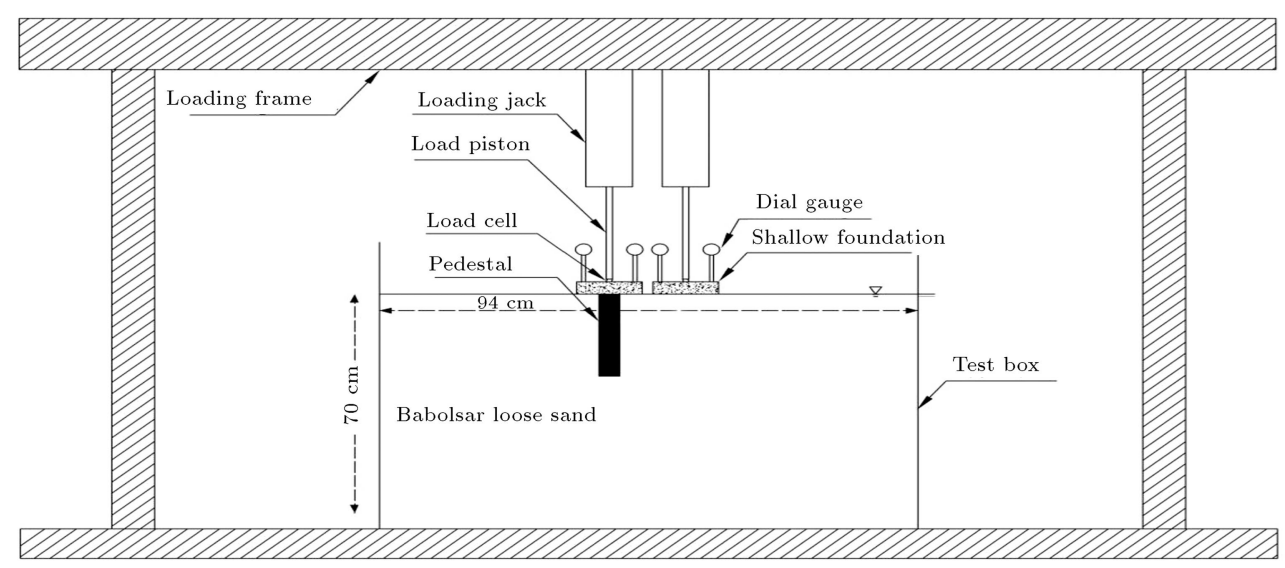

(a)

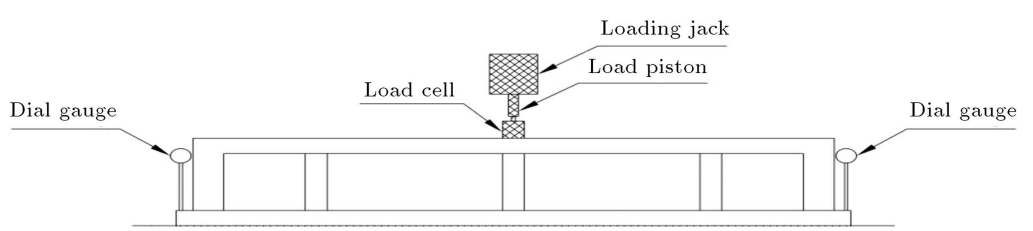

(b)

Figure 3. (a) Schematic view of the experimental setup. (b) Section view of the strip footing with concrete pedestal (dimensions are in centimeters).

Table 2. Scaling factor used to convert the parameters to prototype units [17].

\begin{tabular}{lc}
\hline Parameter & $\begin{array}{c}\text { Scale factor } \\
\text { (prototype/model) }\end{array}$ \\
\hline Length & $N$ \\
Displacement & $N^{(2-\propto)}$ \\
Mass density & 1 \\
Stress and pressure & $N$ \\
Stiffness & $N^{\propto}$ \\
\hline
\end{tabular}

Note: For sands $\propto=0.5$

et al. [20] to account for the correlation of relative density and effective stress level between the model and the prototype scales. For the Babolsar sand (i.e., the sand used in the current study), they decreased the relative density $\left(D_{r}\right)$ of the sand by about $20 \%$ on the model scale in order to compensate for the 10 times smaller effective stress level, leading to a more dilatant behavior in the model test. This type of scaling is commonly used for the $1 \mathrm{~g}$ model tests concerned with large deformation problems (e.g., [21-23]). Therefore, in this study, the loosest state of the Babolsar sand in the $1 \mathrm{~g}$ box was achieved with $D_{r}=30 \pm 2 \%$, which corresponded to $D_{r}=50 \%$ on the prototype scale using the adopted scaling factor $(N=10)$.

\subsection{Experimental and test procedure}

In this study, 16 tests were conducted in two series (first series, Factor of Safety (FS) $=2$; second series, FS $=3$ ) including 10 tests under the unreinforced condition and 6 tests under the reinforced condition; in addition, different safety factors were considered. One test was performed on a single footing as a benchmark for making a comparison between different conditions. Table 3 shows the details of all tests in this study. In general, this research is composed of two main

Table 3. Details of the tests program.

\begin{tabular}{|c|c|c|c|c|}
\hline No. & $\begin{array}{l}\text { Test } \\
\text { code }\end{array}$ & $\begin{array}{c}\text { Test } \\
\text { series }\end{array}$ & $\begin{array}{c}\text { Factor of } \\
\text { Safety (FS) }\end{array}$ & $\begin{array}{c}\text { Clear } \\
\text { space }(\mathrm{S})\end{array}$ \\
\hline 1 & $(\mathrm{St}-1-2-0 \mathrm{~B})^{\mathrm{a}}$ & 1 & 2 & $0 \mathrm{~B}$ \\
\hline 2 & (St-1-2-0.1B) & 1 & 2 & $0.1 \mathrm{~B}$ \\
\hline 3 & (St-1-2-0.3B) & 1 & 2 & $0.3 \mathrm{~B}$ \\
\hline 4 & (St-1-2-0.5B) & 1 & 2 & $0.5 \mathrm{~B}$ \\
\hline 5 & (St-1-2-1B) & 1 & 2 & 1B \\
\hline 6 & $(\mathrm{St}-2-3-0 \mathrm{~B})^{\mathrm{b}}$ & 2 & 3 & oB \\
\hline 7 & (St-2-3-0.1B) & 2 & 3 & $0.1 \mathrm{~B}$ \\
\hline 8 & (St-2-3-0.3B) & 2 & 3 & $0.3 \mathrm{~B}$ \\
\hline 9 & (St-2-3-0.5B) & 2 & 3 & $0.5 \mathrm{~B}$ \\
\hline 10 & $(\mathrm{St}-2-3-1 \mathrm{~B})$ & 2 & 3 & $1 \mathrm{~B}$ \\
\hline 11 & $($ St-1-2-0B)P & 1 & 2 & OB \\
\hline 12 & $($ St-1-2-0.3B)P & 1 & 2 & $0.3 \mathrm{~B}$ \\
\hline 13 & $($ St-1-2-1B)P & 1 & 2 & 1B \\
\hline 14 & $($ St-2-3-0B)P & 2 & 3 & oB \\
\hline 15 & $($ St-2-3-0.3B)P & 2 & 3 & $0.3 \mathrm{~B}$ \\
\hline 16 & $(\mathrm{St}-2-3-1 \mathrm{~B}) \mathrm{P}$ & 2 & 3 & $1 \mathrm{~B}$ \\
\hline
\end{tabular}

Note: $\mathrm{St}=$ Strip footing

a: (Foundation type-First series-Safety Factor-Clear Space);

b: (Foundation type-Second series-Safety Factor-Clear Space). 
test series. In the first series consisting of 10 tests, the interfering effect of a heavy construction (or the new footing) on a previously constructed light (or old) footing within different spacing and safety factors is explored. Then, in the second series, which is the main part of the current study, 6 tests are conducted by adding three concrete pedestals under the new footing with a center-to-center distance of $2.5 D$ (whereas $D$ is the pedestal diameter) in order to study the interfering effect of the new and old footings on the ultimate bearing capacity of the new footing, settlement, and the tilting of the old footing. Different spacing values and two safety factors of 2 and 3 were applied in the experiments. The surcharge of the old footing was determined as part of the ultimate bearing capacity through the initial safety factors of 2 and 3, which are in the same range commonly used in the shallow foundation design. Moreover, the ultimate bearing capacity of the new footing and the settlement of the old footing were altered remarkably by changing the safety factor from 3 to 2 at an $S / B$ ratio of 0 . This effect was mitigated by increasing the clear spacing between the two footings.

Each series has two stages; in the first stage of the first series, a $40 \times 15 \mathrm{~cm}$ strip footing was placed on the saturated sand surface after preparing the saturated sand deposit in the box. Since the length of the strip footing model is equal to the width of the box, a plane-strain condition can be reasonably maintained. Subsequently, the load was applied to the single footing until the bearing capacity reached the ultimate value, which represents the failure displacement (i.e., $20 \%$ of the footing width). It should be noted that, based on the method presented by Vesic [24], the ultimate bearing capacity was defined as the load corresponding to the settlement of 15 to $25 \%$ of the foundation width (in the case of local or punching shear failure). In this study, the considered settlement ratio corresponding to the ultimate bearing capacity was assumed to be $20 \%$ of the footing width (see Figure $4(\mathrm{a})$ to $(\mathrm{d})$ ).

Considering the desired safety factors, the bearing capacity, the settlement, and the tilting of the foundation were measured by three dial gauges installed at the edges of the strip footing. In the second stage, the old footing was loaded to achieve a constant desired weight. Then, a specific clear spacing was considered to place the second footing as representative of the new footing of a heavy building. In the meantime, by keeping the load of the old footing constant, the new footing was loaded up to its ultimate bearing capacity, as shown in Figure 4(b)-(d). Then, the bearing capacity of the new footing due to the adjacency, the settlement, and the tilting of the old footing interfering with the new footing was recorded and compared with the isolated ones.

The second series tests (including 6 ones) are conducted at two stages, the same as those of the first series. However, in this series, the soil underneath the new footing was reinforced by three concrete pedestals with a diameter of $2.5 \mathrm{~cm}$, a depth of $15 \mathrm{~cm}$, and a center-to-center distance of $2.5 \mathrm{D}$. Initially, the sand was poured into the box up to the desired height

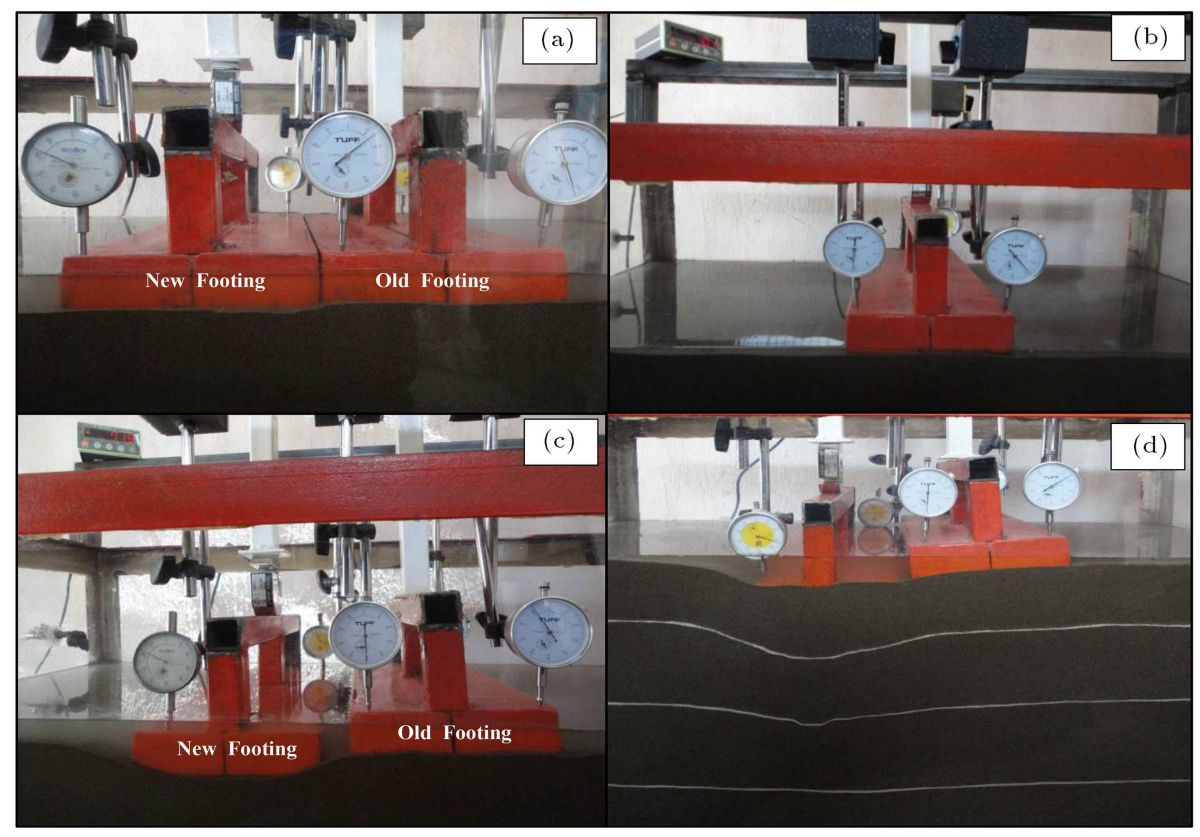

Figure 4. Location of footings in some tests: (a) Two footings at a ratio of $S / B=0$ (before loading on the new footing), (b) isolated footing, (c) the effect of the new footing on the old footing at a ratio of $S / B=0.1$, and (d) the effect of the new footing on the old footing at a ratio of $S / B=0$. 
and, then, three pedestals were placed vertically and restrained through strings. In the next step, the sand raining continued until the specimen reached the top of the surface of the pedestal. After applying the surcharge on the old footing through cutting the strings, the new footing was located on the reinforced sand (by pedestals) and, finally, the tests continued thereafter. Pedestal installation under the new footing results in transferring additional imparted stress to the deeper soil, which decreases the interfering effect of the new footing on the old footing. Figure 5 illustrates the process of concrete pedestal installation for reinforcing the new footing underneath.

The parameters including the ultimate bearing capacity of the new footing, the settlement, and tilting (rotation) of the old footing are investigated in the case of the reinforced soil underneath the new footing, compared with those of the unreinforced footing. The results obtained from this study show that reinforcing the new footing placed adjacent to the old footing causes a significant increase in the bearing capacity of the new footing and a dramatic reduction in the settlement and tilting of the old footing. The details of the results in terms of bearing capacity and settlement indices are described in the next section.

\section{Test results and discussion}

In order to evaluate the effect of the interference factors on the ultimate bearing capacity of unreinforced and reinforced conditions in soil beneath, the new footing due to the old footing adjacency, and the settlement of the old footing resulting from the new footing, $\left(I F_{B}\right)_{n e w},\left(I F_{B}\right)_{n e w}^{\prime},\left(I F_{S}\right)_{o l d}$, and $\left(I F_{S}\right)_{\text {old }}^{\prime}$ are respectively defined as follows:

$$
\begin{aligned}
& \left(I F_{B}\right)_{n e w}=\frac{\left(q_{u-i n t}\right)_{n e w}}{q_{u(\text { single })}}, \\
& \left(I F_{B}\right)_{n e w}^{\prime}=\frac{\left(q_{u-i n t-P}\right)_{n e w}}{q_{u(\text { single })}},
\end{aligned}
$$

$$
\begin{aligned}
\left(I F_{S}\right)_{o l d} & =\frac{\left(\Delta_{\text {int }}\right)_{o l d}}{\Delta_{(\text {single })}}, \\
\left(I F_{S}\right)_{o l d}^{\prime} & =\frac{\left(\Delta_{\text {int-P }}\right)_{o l d}}{\Delta_{(\text {single })}},
\end{aligned}
$$

where $\left(q_{u-i n t}\right)_{n e w}$ and $\left(q_{u-i n t-P}\right)_{n e w}$ are the ultimate bearing capacity of the new footing in the presence of the old footing under unreinforced and reinforced (with concrete pedestal) conditions, respectively. Further, $\left(\Delta_{\text {int }}\right)_{\text {old }}$ and $\left(\Delta_{\text {int-P }}\right)_{\text {old }}$ are the settlement of the old footing for the considered safety factors as the result of the new footing surcharge under unreinforced and reinforced (with concrete pedestal) conditions, respectively. Herein, $q_{u(\text { single) }}$ and $\Delta_{\text {(single) }}$ are the ultimate bearing capacity and the settlement of the isolated footing (known as the old footing), respectively, for the considered safety factors.

\subsection{Ultimate bearing capacity of interfering footings}

To achieve a reliable estimate of the interference effect on the bearing capacity, the settlement, and the tilting, a foundation model was placed at the center of the testing box at first and loaded up to the point of failure. Then, the stress-settlement curves of the tests were plotted on a single footing, as shown in Figure 6(a). The desired safety factors were considered as the counterparts of the final surcharge applied for each of the old footings located nearby the new footings. Then, the new footing (with the same size of the old footing) was placed close to the old footing, while it was loaded to the point of failure (through a strain control manner) by considering different clear spacing distances $(S)$. It should be noted that the midpoint of the clear spacing coincides with the middle of the testing box. Afterward, the contact stress of the new footing was measured, as plotted in Figure 6(a).

Figure 6(a) presents the stress-settlement curves of ten tests on the two nearby footings plus one test associated with the single footing. Accordingly, the stress-settlement curves of all double foundation tests

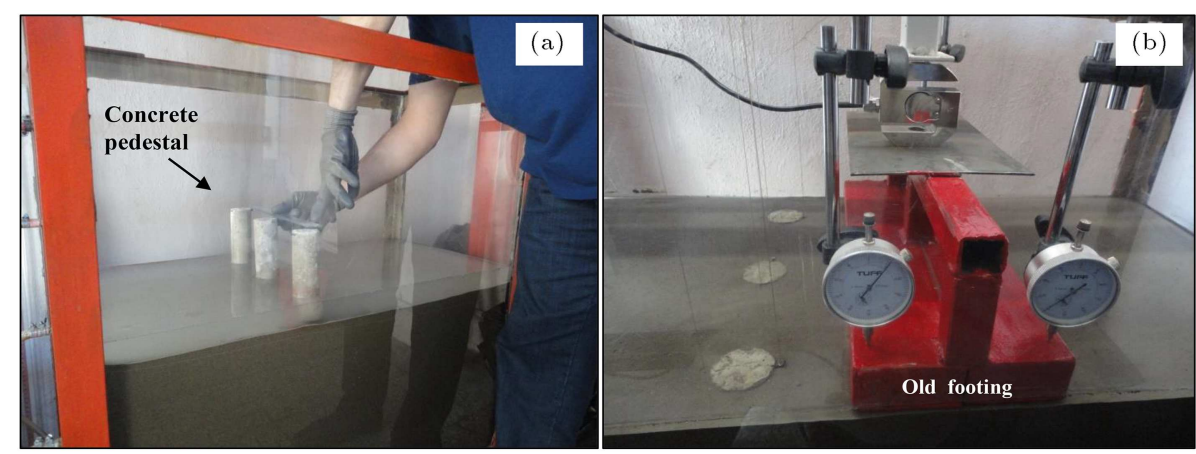

Figure 5. (a) Process of concrete pedestal installation for reinforcing the new footing underneath. (b) Location of the old footing adjacent to installed concrete pedestals (reinforced) before insertion the new footing. 


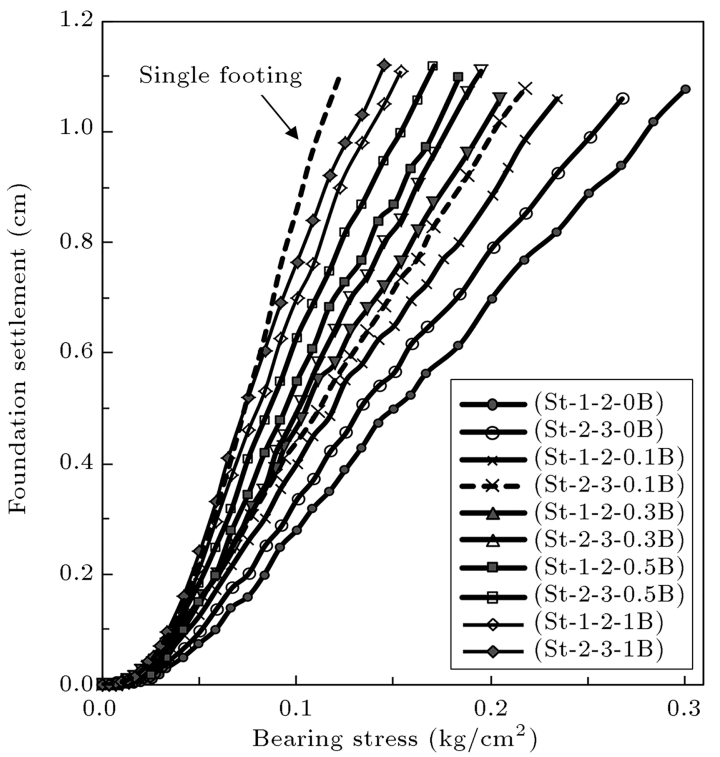

(a)

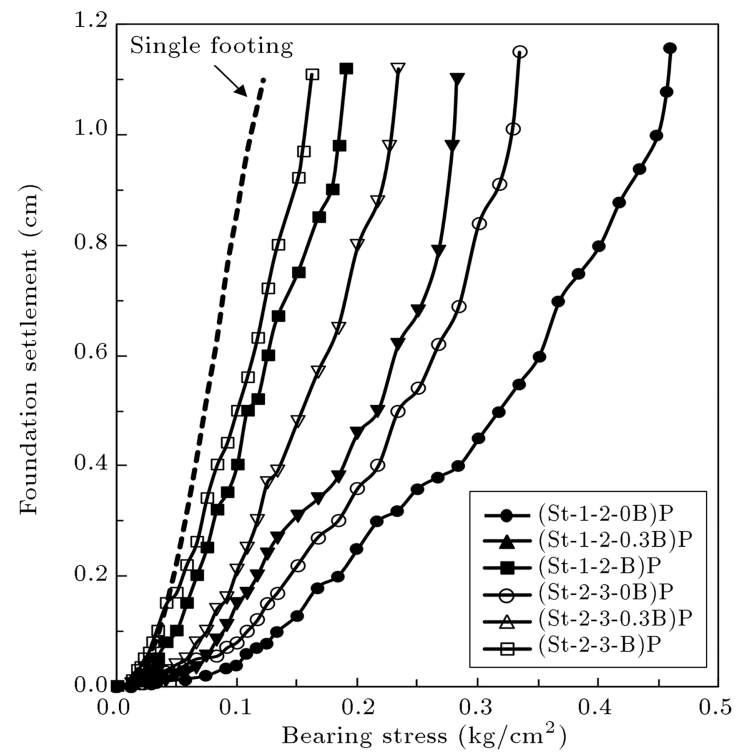

(b)

Figure 6. Bearing capacity versus foundation settlement for (a) ten tests containing the first and second series of tests under unreinforced conditions and (b) six tests containing the first and second series of tests under reinforced conditions (with concrete pedestals).

are located on the right-hand side of the single footing's curve. It is indicated that the bearing capacity increases due to the presence of the new footing adjacent to the old footing. The amount of bearing capacity increase depends on the different spacing of the foundations and the safety factor (2 or 3 ) considered for the old footing. As observed, by decreasing the clear spacing between the two foundations, the stress-settlement curve experiences an increase in the bearing capacity of the new footing. Note that the bearing capacity is defined as the value of contact stress corresponding to the failure settlement ( $20 \%$ of footing width).
Figure 6(b) illustrates the curves of bearing capacity versus the settlement of six tests for the new footing placed adjacent to the old footing when concrete pedestals with $5 \mathrm{~cm}$ in diameter, $15 \mathrm{~cm}$ in depth, and a center-to-center distance of $2.5 \mathrm{D}$ have been utilized underneath the new footing. Further, the graph with dashed lines belongs to the bearing capacity versus the settlement of a single footing. Figure 6(b) shows that the bearing capacity of the new footing adjacent to the old footing increases remarkably by placing the pedestals, compared to that of a single footing. However, this enhancement depends on the spacing between the footings. In the six tests conducted under the reinforced condition and for two coherent footings $(S / B=0)$, the bearing capacity of the new footing has the highest level of increase, compared to the rest of the considered conditions. It should be noted that three out of the six conducted tests on the old footing under the reinforced condition have a safety factor of 3, whereas the other three tests have a safety factor of 2 .

As shown in Figure $7,\left(I F_{B}\right)_{n e w}$ and $\left(I F_{B}\right)_{\text {new }}^{\prime}$ defined as the ultimate bearing capacities of the new footings, compared with a single footing, are investigated under both unreinforced and reinforced soil conditions underneath the new footing at different $S / B$ ratios, respectively. $\left(I F_{B}\right)_{n e w}$ is a non-dimensional parameter used to describe the interfering effect on the bearing capacity and settlement of the two adjacent footings compared with a single footing. It can be clearly observed that, at $S / B=0$ in the first and second series of tests, the $\left(I F_{B}\right)_{n e w}$ of the unreinforced soil is 3.855 and 2.9. However, reinforcing the soil by a pedestal (i.e., 3 concrete pedestals with a center-to-center distance of $2.5 \mathrm{D})$ increases the $\left(I F_{B}\right)_{\text {new }}^{\prime}$ significantly at $S / B=0$, whereas it reaches 6.47 and 4.7 in the first $(F S=2)$ and second $(F S=3)$ series of tests, respectively. In other words, the application of the reinforcement

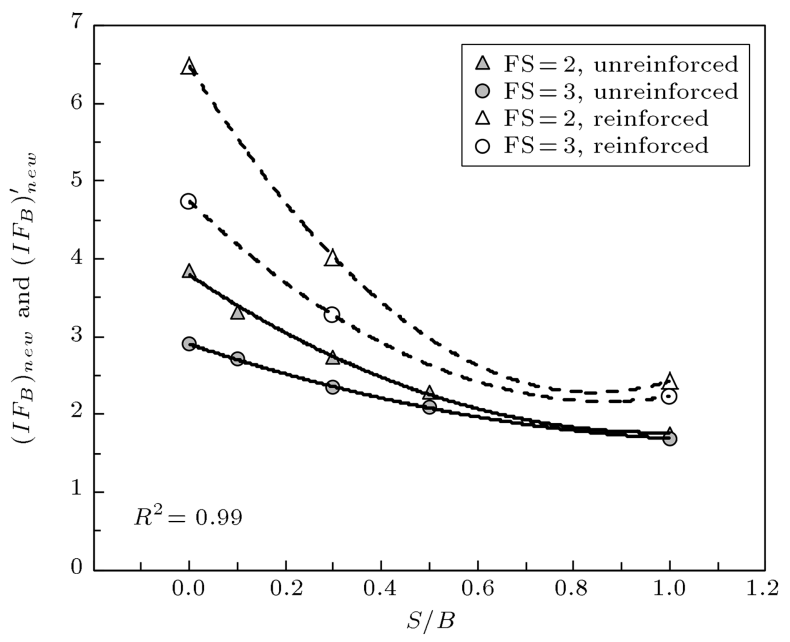

Figure 7. Interference factor of bearing capacity versus $S / B$ ratios under reinforced and unreinforced conditions. 
technique for improving the new footings leads to an increase in the $\left(I F_{B}\right)_{\text {new }}^{\prime}$ of $S / B=0$ ratio up to $67 \%$ and $62 \%$ in $F S=2$ and $F S=3$, respectively. This increase leads to a reduction in the imposed additional stress bubbles from the new footings to the old ones.

Although the $\left(I F_{B}\right)_{\text {new }}^{\prime}$ of $S / B=1,0.3$, and 0 is higher in the reinforced state than that in the unreinforced one, this difference is greater than the other two ratios at $S / B=0$. For example, at $S / B=1$, where the spacing between the two footings is equal to the footing width, the $\left(I F_{B}\right)_{n e w}^{\prime}$ in the first and second series of tests with the reinforced soil foundation by pedestals is $38 \%$ and $32 \%$ greater than that in the unreinforced condition $\left(\left(I F_{B}\right)_{n e w}\right)$, respectively. In other words, although the spacing between both footings is equal to their footing width, the ultimate bearing capacity under the new footing increases by as much as 2 times that of a single footing due to pedestal installation. As a result, the interfering effect of the new footing on the old footing decreases dramatically. Figure 7 indicates that $\left(I F_{B}\right)_{\text {new }}^{\prime}$ of the first series of tests is greater than that of the second ones at a constant $S / B$ ratio. For example, $\left(I F_{B}\right)_{\text {new }}^{\prime}$ of $S / B=0$ under the reinforced condition experiences a $37.7 \%$ increase in the first series rather than in the second one, whereas this increase is $33 \%$ under the unreinforced condition. Increasing the $S / B$ ratio causes a decrease in the safety factor influence of $\left(I F_{B}\right)_{n e w}$ and $\left(I F_{B}\right)_{n e w}^{\prime}$; at $S / B=1$, the difference in the safety factor of the two considered series of tests is only $9 \%$ and $4 \%$ under the reinforced and unreinforced conditions, respectively.

\subsection{Settlement of interfering footings}

The effect of the interference on the settlement of adjacent strip footings in reinforced and unreinforced conditions (concrete pedestal) at the ultimate bearing pressure is studied. Figure 8 demonstrates the nondimensional parameters, $\left(I F_{S}\right)_{\text {old }}$ and $\left(I F_{S}\right)_{\text {old }}^{\prime}$, that

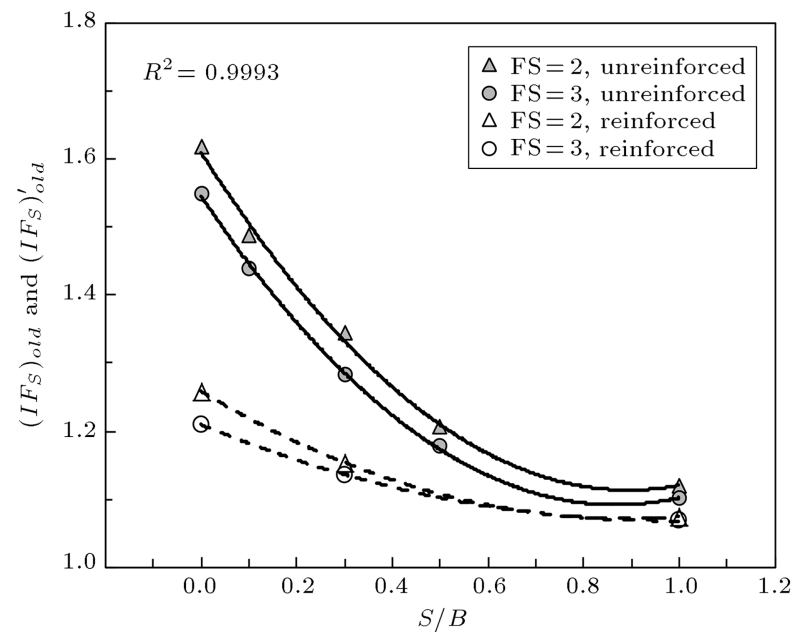

Figure 8. Interference factor of settlement versus $S / B$ ratios under reinforced and unreinforced conditions. are defined as the settlement of the old footing due to the interference of the new footings in unreinforced and reinforced conditions, respectively, compared to that in a single footing. $\left(I F_{S}\right)_{\text {old }}^{\prime}$, which is the effective interfering coefficient of the old footing due to the presence of the new footing, shows a remarkable decrease by installing the pedestal under the new footing compared with the non-pedestal condition. For example, $\left(I F_{S}\right)_{\text {old }}$ at $S / B=0$ is 1.62 and 1.55 in the unreinforced condition in the first and second series of tests, respectively. However, given the same $S / B$ ratio while reinforcing the new footing by the pedestal, $\left(I F_{S}\right)_{\text {old }}^{\prime}$ is 1.258 and 1.2 in the unreinforced condition in the first and second series of tests, respectively. Therefore, at $S / B=0$ ratio, the $\left(I F_{S}\right)_{\text {old }}$ experiences a $29 \%$ decrease in the first and second series of tests in both of the reinforced and unreinforced conditions. A decrease of roughly $30 \%$ in the $\left(I F_{S}\right)_{\text {old }}^{\prime}$ due to the presence of pedestal under the new footing has a low-level effect on the old footing. The $\left(I F_{S}\right)_{\text {old }}$ and $\left(I F_{S}\right)_{\text {old }}^{\prime}$ in both series of tests (first and second) under both of the defined conditions (reinforced and unreinforced) reach the minimum value at $S / B=1$ ratio. In other words, increasing the spacing between the two coherent footings $(S / B=0)$ up to the width of footings $(S / B=1)$ causes a significant decrease in the rate of $\left(I F_{S}\right)_{\text {old }}$. However, these variations are negligible for different safety factors and for both reinforced and unreinforced conditions.

Figure 9 shows that increasing the $S / B$ ratio in both series of tests and under both reinforced and unreinforced conditions causes a significant reduction in the differential settlement of the old footing due to its adjacency to the new footing, whereas the old footing adjacency to the new footing results in an increase in the old footing settlement at all of the considered $S / B$ ratios, compared with a single footing. Considering the maximum allowable foundation's settlement $(51 \mathrm{~mm}$

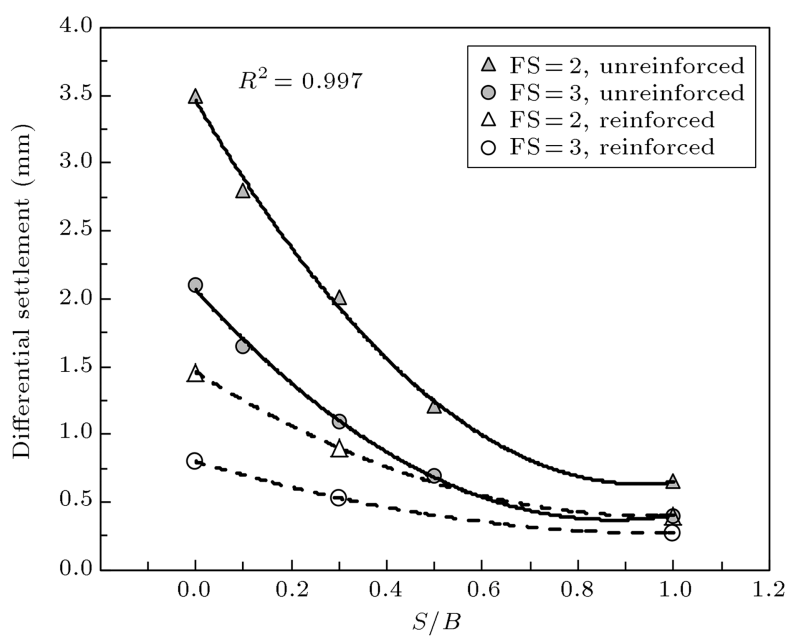

Figure 9. Differential settlement of the old footing versus $S / B$ ratios under reinforced and unreinforced conditions. 
on the prototype scale) suggested by Skempton and MacDonald [25] in the sand, the maximum allowable settlement on the model scale is obtained as equal to $1.61 \mathrm{~mm}(51 \times 0.0316)$. Thus, in an unreinforced condition and given the interference of two footings, the differential settlement of the old footing in the five series of tests including (st-1-2-0B), (st-1-2-0.1B), (st1-2-0.3B), (st-2-3-0B), and (st-2-3-0.1B) exceeds the allowable settlement, leading to a damaging situation for the old building.

As shown in Figure 9, the reinforcement of the new footing by a concrete pedestal with the diameter of $5 \mathrm{~cm}$ and the depth of $15 \mathrm{~cm}(L / D=3)$ leads to the remarkable mitigation of the effect of the new footing on the old footing settlement. For example, at an $S / B$ ratio of 0 in the series of tests, when the new footing is reinforced underneath by a pedestal, the old footing differential settlement for adjacency to the new footing decreases by $240 \%$ compared to the unreinforced condition, whereas the reduction is $262 \%$ in the same condition for the second series of tests.

Moreover, when $S / B=1$ (the spacing between the two footings is equal to $B$ ), the differential settlement of the old footing due to the adjacency of the new footing under the reinforced condition decreases in the first and second series of tests by $63 \%$ and $48 \%$, respectively, compared to that under the unreinforced condition.

The main point is that although the pedestal is applied as a component for transferring the imposed additional inductive stress bubbles to the deeper parts of the soil, the effects of the new footing on the old footing settlements reduces until the reduction of the differential settlement of the old footing by reinforcing the new footing with pedestal reaches less than the allowable settlement value in all tests.

As seen in Figure 10, at $S / B=0$, the settlement ratio in the first and second series of tests under the unreinforced condition is 0.62 and 0.55 , respectively, which respectively decreases to 0.26 and 0.2 under the reinforced condition. The same conditions hold at $S / B=1$, while the settlement ratio is 0.12 and 0.1 in the first and second series of tests in the unreinforced condition, which is respectively reduced to 0.07 and 0.06 by applying the concrete pedestal as a stabilizer.

The settlement ratio of $S / B=0$ in the first and second series of tests under the unreinforced condition is respectively 5.15 and 5.43 times greater than that at an $S / B$ ratio of 1 . However, the application of the pedestal underneath the new footing can facilitate determining the settlement ratio at an $S / B$ ratio of 0 , which is 3.48 and 3 times greater than that at $S / B=1$ in the first and second series of tests, respectively.

Figure 11 reveals the role of pedestal installation underneath the new footing in increasing its bearing capacity and, consequently, a remarkable decrease in

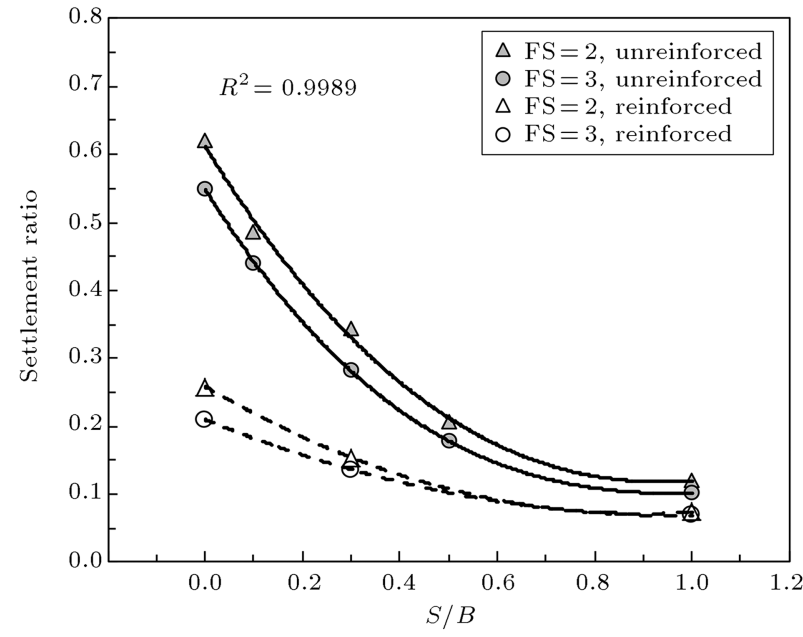

Figure 10. Settlement ratio versus $S / B$ ratios (the old footing resultant from the new footing) under reinforced and unreinforced conditions.

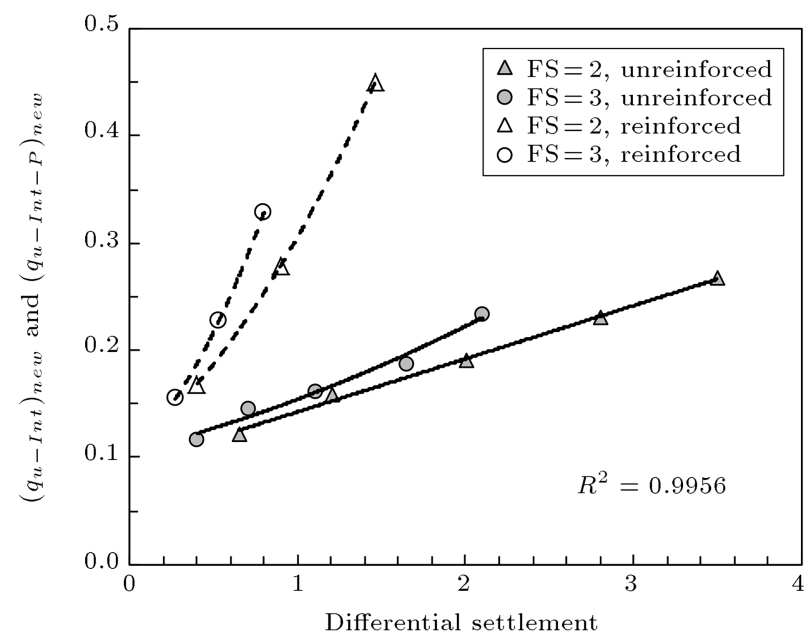

Figure 11. Ultimate bearing capacity of interfering versus differential settlement of the old footing resulting from the new footing under reinforced and unreinforced conditions.

the settlement of the old footing in both series of tests. In other words, the reinforcement of the soil underneath the new footing transfers the imposed additional inductive stress bubbles produced by the new footing (heavy buildings sample) to the deeper parts of the soil instead of the old footing. Moreover, in five out of the ten tests conducted under the unreinforced condition, the adjacency of the old footing to new footing results in exceeding the old footing settlement from the allowable value. However, because of the above-mentioned reasons, the application of a pedestal decreases the settlement of the old footing up to the allowable amount in all tests entirely.

In Figure 12, $\left(I F_{B}\right)_{\text {new }}^{\prime}$ in the first and second series of tests at $S / B=0$ under the reinforced condition compared to that of the unreinforced condition 


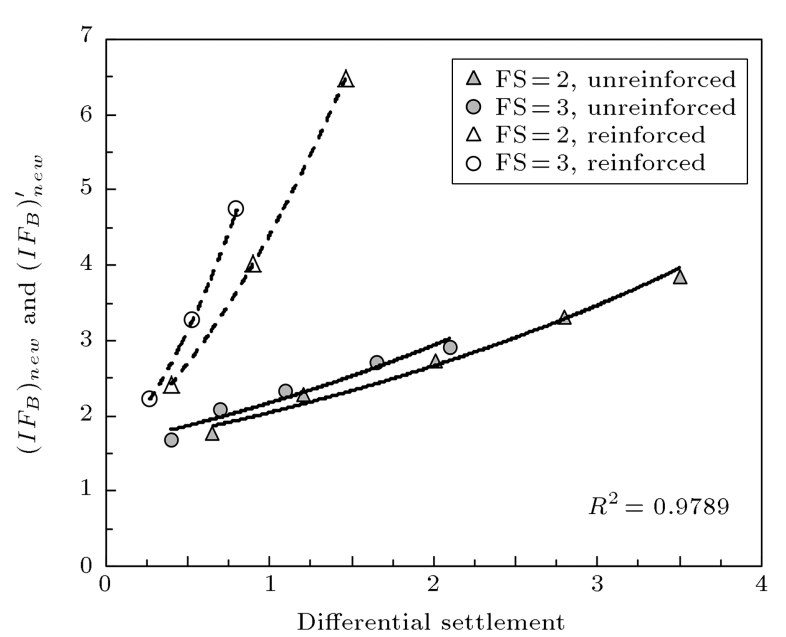

Figure 12. Interference factor of bearing capacity versus differential settlement of old footing resulting from the new footing under reinforced and unreinforced conditions.

is 4.07 and 3.7 times greater than that at $S / B=$ 1 , respectively. Under the reinforced condition, the reduction of the old footing settlement between the ratios of $S / B=0$ and 1 is the result of a great increase in the $\left(I F_{B}\right)_{\text {new }}$ amount due to the stabilization of the soil underneath the new footing with 3 pedestals $(L / D=3)$.

To determine the degree of the reinforcement effect on the soil beneath the new footing by means of 3 concrete pedestals used for reducing the settlement of the old footing resulting from interference of the new footing, the Settlement Reduction Ratio (SRR) is defined as follows:

$$
S R R=\frac{S_{(\text {reinforced })}-S_{(\text {unreinforced })}}{S_{(\text {unreinforced })}},
$$

where $S_{\text {(reinforced) }}$ and $S_{\text {(unreinforced) }}$ are the settlement of the old footing at the desired safety factor in the presence of the new footing in reinforced (with concrete pedestal) and unreinforced conditions, respectively.

Figure 13 shows the (SRR) versus different $S / B$ ratios for the two supposed safety factors of 2 and 3 . As mentioned before, a reduction in the settlement ratio is defined as the settlement differential between the reinforced and unreinforced conditions of the old footing adjacent to the new footing compared to that of the old footing adjacent to the new footing in an unreinforced condition.

At an $S / B$ ratio of 0 , for the first $(F S=2)$ and second $(F S=3)$ series of tests, the (SRR) is $58 \%$ and $62 \%$, respectively. At $S / B=1$, the (SRR) for the old footing due to the reinforcement of the soil underneath the new footing with concrete pedestals reaches the minimum. For example, at an $S / B$ ratio of 1 , the SRR rate in the first and second series of tests is $32 \%$ and $38 \%$, respectively.

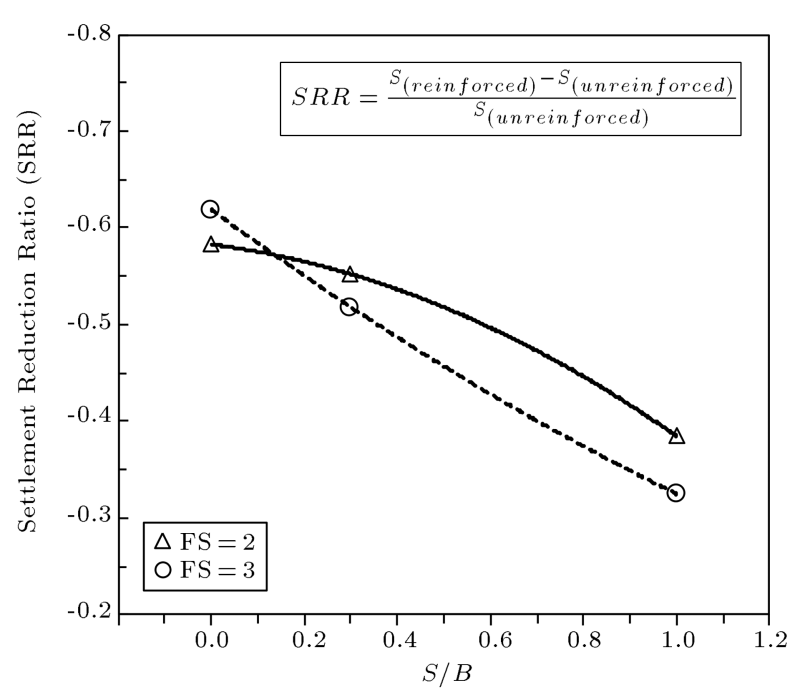

Figure 13. Variation of Settlement Reduction Ratio (SRR) versus $S / B$ ratio.

\subsection{Tilting of interfering footings}

In this section, the effect of interference on the tilting of the old footing resulting from the adjacency of the new footing surcharge in reinforced and unreinforced conditions (concrete pedestal) is investigated. According to Figure 14, the interfering effect of the two footings on the old footing tilting is remarkably great under the unreinforced condition (when no pedestal exists). At $S / B=0$, the tilting under the unreinforced condition is 0.68 and 0.62 degrees in the first and second series of tests, respectively. At $S / B=1$ ratio (spacing equal to the footing's width), the old footing tilting due to its adjacency to the new footing reaches a minimum value in both series of tests. The main point is that, in all of the ten tests conducted under the unreinforced condition, the old footing tilting due to its adjacency to the new footing exceeds the allowable

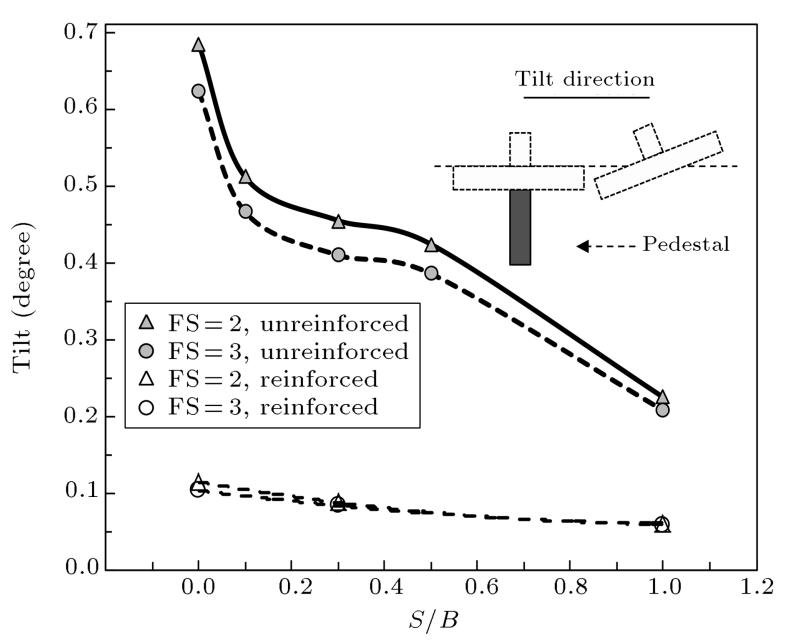

Figure 14. Tilting of the old footing resulting from the new footing versus $S / B$ ratios under reinforced and unreinforced conditions. 
tilting ratio, which causes irreparable damage to light buildings because of their adjacency to heavy buildings. However, the placement of 3 concrete pedestals under the new footing as a mitigating measure for transferring the applied stress from heavy buildings to the deeper parts of the soil leads to the mitigation of the effect of the new reinforced footing on the tilting of the old footing. In a reinforced condition, the old footing tilting reaches 0.11 and 0.05 degrees in the first and second series of tests, respectively, when $S / B$ is 0 . In other words, this tilting value is 6 times less than that under the unreinforced condition. At $S / B=1$ (the lowest tilting condition of the old footing), the reinforcement of the old footings reduces the tilting of the old footing by as much as 3 times, compared to that in the unreinforced condition. It should be mentioned that the application of 3 concrete pedestals at $L / D=3$ ratio (5 $\mathrm{cm}$ in diameter and $15 \mathrm{~cm}$ in length) decreases the old footing tilting up to the allowable ratio in all of the conducted tests.

Figure 15 reveals that reinforcing the soil underneath the new footing increases significantly the ultimate bearing capacity of the new footing in both series of tests. In contrast, the tilting of the old footing decreases by the new footing reinforcement. For example, at $S / B=0$ (i.e., the two coherent footings), the ultimate bearing capacity of the new footing in the first and second series of tests increases by $68 \%$ and $40 \%$, respectively, under the reinforced condition, compared to that in the unreinforced condition. However, with the same condition and in both series of tests, the tilting of the old footing reduces by up to 6 times, compared to that in the unreinforced condition. Under both reinforced and unreinforced conditions, the effect of changing the safety factor from $F S=2$ to $F S=3$ was negligible on the old footing tilting. Moreover, compared with the unreinforced case, $\left(q_{u-i n t}\right)_{n e w}$ of

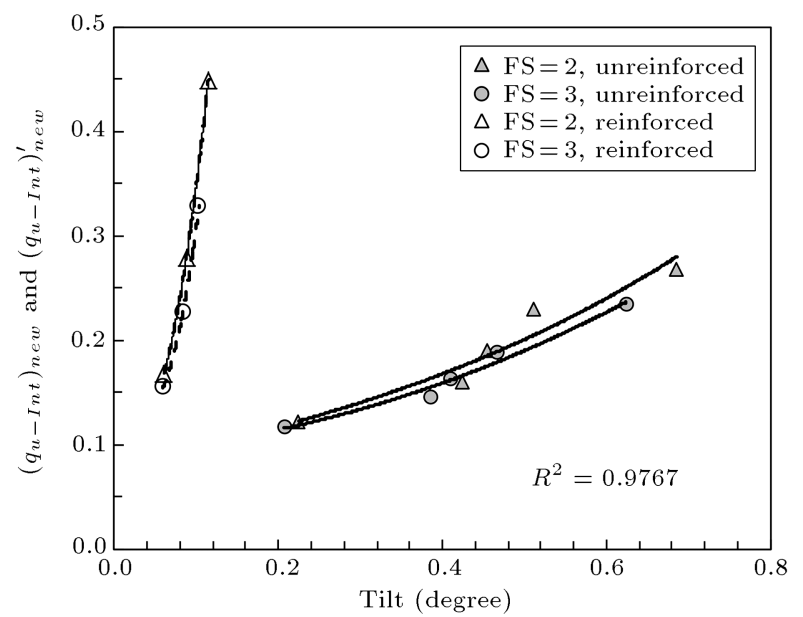

Figure 15. Ultimate bearing capacity of interfering versus tilting of the old footing resulting from the new footing under reinforced and unreinforced conditions.

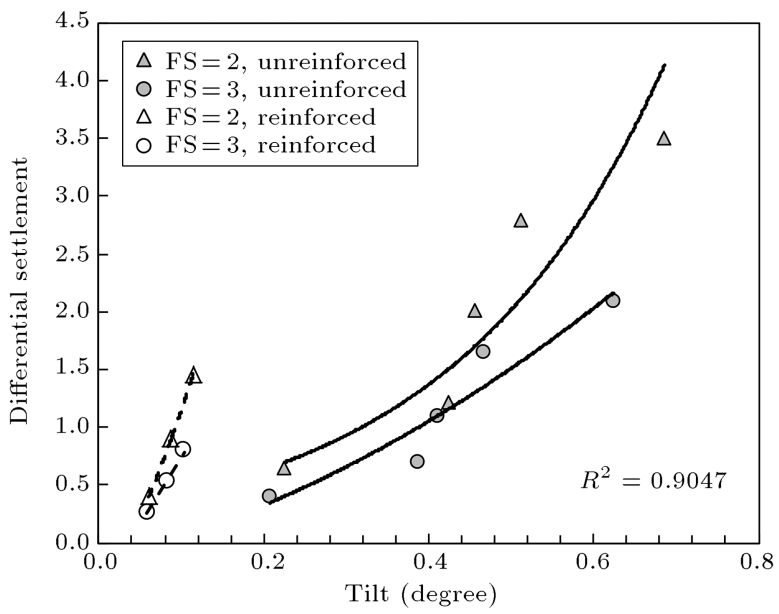

Figure 16. Differential settlement of the old footing resulting from the new footing versus tilting of the old footing under reinforced and unreinforced conditions.

$S / B=0$ under the reinforced condition is 3.79 and 2.53 times greater than that at $S / B=1$ in the first and second series of tests, respectively. At $S / B=0$, the tilting of the old footing under the reinforced condition reduces by 3.5 times in both series of tests, compared to that at $S / B=1$.

Figure 16 confirms the results obtained in the previous charts, indicating a remarkable reduction in the effect of the new footing on the old footing by applying 3 pedestals and, consequently, a reduction in the differential settlement and tilting of the old footing. For example, in the first series of tests at $S / B=0$, the differential settlement and tilting of the old footing due to their adjacency to the new footing under the reinforced condition reduce by 8 and 3.5 times, compared to that at $S / B=1$. With the same condition defined in the second series of tests, the differential settlement and tilting of the old footing undergo reduction by 10 and 3.66 times. The mentioned results highlight the reducing effect of the new footing reinforcement on the old footing settlement, resulting in a great decrease in the old footing tilting.

\section{Conclusions}

In this study, the load-deformation mechanism of the two nearby strip footings on saturated sand was investigated. The footings were placed in a consecutive manner, whereas the surcharges were unequal and nonsimultaneous. In total, 16 tests were conducted by utilizing small-scale $1 \mathrm{~g}$ model tests, whereas 10 tests were carried out under the unreinforced condition and the rest of 6 tests done under the reinforced condition. In the reinforced condition, the soil underneath the new footing was stabilized by concrete pedestals. The following results are drawn: 
1. The interference of two adjacent footings in which one resembles a heavy building's footing (the new footing) and the other represents a light building's footing (the old footing) had an outstanding effect on the bearing capacity of the new footing, settlement, and tilting (rotation) of the old footing under both reinforced and unreinforced conditions;

2. The amount of $\left(I F_{B}\right)_{n e w}$ at $S / B=0$ experienced an increase by $67 \%$ and $62 \%$ in the first and second series of tests, respectively, under the reinforced condition, compared to the unreinforced condition;

3. In the first and second series of tests at $S / B=$ 0 , the differential settlement of the old footing due to the new footing adjacency underwent a reduction by $240 \%$ and $262 \%$, respectively, under the reinforced condition $\left(\left(I F_{B}\right)_{n e w}^{\prime}\right)$, compared to the unreinforced condition;

4. At $S / B=0$, the tilting or rotation of the old footing due to the adjacency to the new footing reduced up to 6 times under the reinforced condition, compared to the unreinforced condition;

5. The Settlement Reduction Ratio (SRR) of the old footing adjacent to the new footing at $S / B=0$ was $58 \%$ and $62 \%$ in the first and second series of tests, respectively;

6. In both reinforced and unreinforced conditions, changing the safety factor had a negligible effect on the tilting of the old footing placed close to the new footing;

7. Among the 10 tests conducted under the unreinforced condition and footing adjacency, the settlement of the old footing exceeded the allowable settlement in 5 tests; however, in the same condition, the tilting of the old footing exceeded the allowable tilting in all the 10 performed tests, which may cause irreparable structural damages to the foundation of the light buildings (the old footing) resulting from heavy structures;

8. The results indicated that the application of concrete pedestals as the soil stabilizer beneath the shallow footings (neither settlements nor tilting) reached the allowable level. In other words, using three concrete pedestals at $L / D=3$ beneath the new footing had a notable role in decreasing the settlement and tilting of the old footing and increasing the ultimate bearing capacity of the new footing;

9. In terms of the tilting and settlement of the old footing, the results indicated a tremendous effect of the old footing surcharge on these parameters attributed to its adjacency to the new footing. It needs to be noted that the highest impact of the old footing surcharge on its tilting and settlement values was observed at an $S / B$ ratio of 0 . This impact decreased with increasing the clear spacing between the footings.

\section{Nomenclature}

$B$

$D$

$D_{r}$

$\left(I F_{B}\right)_{n e w}$

$\left(I F_{B}\right)_{\text {new }}^{\prime}$

$\left(I F_{S}\right)_{\text {old }}$

$\left(I F_{S}\right)_{\text {old }}^{\prime}$

$F S$

$L$

$S$

SRR

$S_{(\text {reinforced })}$

S(reinforced)

$S_{\text {(unreinforced) }}$ Settlement of the old footing with the desired safety factor in the presence of the new footing in the unreinforced condition

$\left(q_{u-\text { Int }}\right)_{\text {new }} \quad$ Ultimate bearing capacity of the new footing in the presence of the old footing

$\left(q_{u-I n t-P}\right)_{n e w}$ Ultimate bearing capacity of stabilizing the new footing in the presence of the old footing

$q_{u(\text { single })}$

$\left(\Delta_{\text {int }}\right)_{\text {old }}$

$\left(\Delta_{\text {int-P }}\right)_{\text {old }}$

Ultimate bearing capacity of old isolated footing at failure with desired safety factors

Settlement of the old footing with the desired safety factor in the presence of the new footing with the desired safety factor in the presence of the new footing

$\Delta_{\text {(single) }} \quad$ Settlement of old isolated footing at failure with desired safety factors

\section{References}

1. Stuart, J.G. "Interference between foundations, with special reference to surface footings in sand", Géotechnique, 12(1), pp. 15-22 (1962). 
2. Ghazavi, M. and Alimardani Lavasan, A. "Interference effect of shallow foundations constructed on sand reinforced with geosynthetics", Geotextiles and Geomembranes, 26, pp. 404-415 (2008).

3. Kouzer, K.M. and Kumar, J. "Ultimate bearing capacity of a footing considering the interference of an existing footing on sand", Geotechnical and Geological Engineering, 28, pp. 457-470 (2010).

4. Ghazavi, M. and Alimardani Lavasan, A. "Behavior of closely spaced square and circular footings on reinforced sand", Soils and Foundations, 52(1), pp. 160-167 (2012).

5. Srinivasan, V. and Ghosh, P. "Experimental investigation on interaction problem of two nearby circular footings on layered cohesionless soil", Geomechanics and Geoengineering, 8(2), pp. 97-106 (2013).

6. Noorzad, R. and Manavirad, E. "Bearing capacity of two close strip footing on soft clay with geotextile", Arabian Journal of Geoscience, 7(2), pp. 623-639 (2014).

7. Ghosh, P., Basudhar, P.K., Srinivasan, V., and Kunal, K. "Experimental studies on interference of two angular footings resting on surface of two layer cohesionless soil deposit", International Journal of Geotechnical Engineering, 9(4), pp. 422-433 (2015).

8. Nainegali, L., Basudhar, P.K., and Ghosh, P. "Interference of two asymmetric closely spaced strip footings resting on nonhomogeneous and linearly elastic soil bed", International Journal of Geomechanics, 13(6), pp. 840-851 (2013).

9. Salamatpoor, S., Jafarian, Y., and Hajiannia, A. "Bearing capacity and uneven settlement of consecutively-constructed adjacent footings rested on saturated sand using model tests", International Journal of Civil Engineering, 17, pp. 737-749 (2019). DOI: $10.1007 / \mathrm{s} 40999-018-0295-\mathrm{y}$

10. ASTM D422, Standard Test Method for Particle-Size Analysis of Soils, ASTM International, West Conshohocken, PA (2003).

11. Jafarian, Y., Ghorbani, A., Salamatpoor S., and Salamatpoor, S. "Monotonic triaxial experiments to evaluate steady-state and liquefaction susceptibility of Babolsar sand", Journal of Zhejiang University Science-A, 14(10), pp. 739-750 (2013).

12. Jafarian, Y., Mehrzad, B., Lee, C.J., and Haddad, A.H. "Centrifuge modeling of seismic foundationsoil-foundation interaction on liquefiable sand", Soil Dynamics and Earthquake Engineering, 97, pp. 184-204 (2017).

13. Salamatpoor, S. and Salamatpoor, S. "Evaluation of Babolsar sand behaviour by using static triaxial tests and comparison with case history", Open Journal of Civil Engineering, 4(3), pp. 181-197 (2014).
14. ASTM C150/C150M-17 "Standard specification for Portland cement", ASTM International, West Conshohocken, PA (2017).

15. Salamatpoor, S., Jafarian, Y., and Hajiannia, A. "Improvement of shallow foundations rested on saturated loose sand by zeolite-cement mixture: a laboratory study", Scientia Iranica, A, 25(4), pp. 2063-2076 (2018). DOI: 10.24200/SCI.2018.50153.1567

16. ASTM D1194-72, Standard Test Method for Bearing Capacity of Soil for Static Load and Spread Footings, ASTM International, West Conshohocken, PA (1987).

17. Wood, D.M., Geotechnical Modeling, E. \& F.N. Spon press, London (2004).

18. Jafarian. Y., Haddad, A., and Mehrzad, B. "Loadsettlement mechanism of shallow foundations rested on saturated sand with upward seepage", International Journal of Geomechanics, 17(3), pp. 1-14 (2016).

19. Vargas-Monge, W. "Ring shear tests on large deformation of sand", Ph.D Thesis, University of Tokyo (1998).

20. Bishop, A.W., Green, G.E., Garga, V.K., Andresen, A., and Brown, J.D. "A new ring shear apparatus and its application to the measurement of residual strength", Géotechnique, 21(4), pp. 273-328 (1971).

21. Iai, S. "Similitude for shaking table tests on soilstructure-fluid model in $1 \mathrm{~g}$ gravitational field", Soils and Foundations, 29(1), pp. 105-118 (1989).

22. Towhata, I., Earthquake Geotechnical Engineering, Springer, Berlin (2007).

23. Otsubo, M., Towhata, I., Hayashida, T., Liu, B., and Goto, S. "Shaking table tests on liquefaction mitigation of embedded lifelines by backfill with recycled materials", Soils and Foundations, 56(3), pp. 365-378 (2016).

24. Vesic, A.S. "Analysis of ultimate loads of shallow foundations", Journal of the Soil Mechanics and Foundations Division, 99(1), pp. 45-73 (1973).

25. Skempton, A.W. and MacDonald, D.H. "The allowable settlement of building", In Proceeding in Institute of Civil Engineering, 5, pp. 727-768 (1956).

\section{Biographies}

Siavash Salamatpoor is currently a $\mathrm{PhD}$ candidate in Geotechnical Engineering at Islamic Azad University of Najafabad, Iran. He received his BSc (1999) and MSc (2012) degrees, respectively, in Civil Engineering from University of Mazandaran and Geotechnical Engineering from University of Guilan, Iran, respectively. His research interests include: saturated and unsaturated soil behavior; ground improvement; foundation engineering; numerical and physical modeling of geotechnical and geo-environmental systems.

Yaser Jafarian is currently the faculty member of International Institute of Earthquake Engineering and Seismology (IIEES). He started the academic activity 
as Assistant Professor at the Civil Engineering Department of Semnan University since 2009 and then moved to IIEES. His professional research fields involve multiple areas of geotechnical earthquake engineering including dynamic soil properties, soil liquefaction, seismic stability and displacement of earth slopes, probabilistic geohazard analysis, and dynamics analysis of seafront structures. Currently, he has focused on physical and numerical modeling of foundations and quay walls tolerating large seismic ground deformations such as liquefaction condition. He have also been involved in analysis and design of various routine and complicated projects including geotechnical site investigation, soil improvement (micropile, stone column, nailing, etc.), analysis and design of marine geotechnical structures (breakwater, quay walls, etc).

Alborz Hajiannia is an Assistant Professor in Department of Civil Engineering in Islamic Azad University of Najafabad, Isfahan, Iran. He received his MSc (2000) and PhD (2012) degrees in Geotechnical Engineering from Amirkabir University of Technology, Tehran, Iran. His research interests are numerical and experimental investigations of soil improvement, advance soil mechanic, geotechnical earthquake engineering, slope stability and foundation engineering. 